\title{
Murine Mucopolysaccharidosis Type VII: Long Term Therapeutic Effects of Enzyme Replacement and Enzyme Replacement Followed by Bone Marrow Transplantation
}

\author{
Mark S. Sands, ${ }^{\star}$ Carole Vogler, ${ }^{\ddagger}$ Aletha Torrey, $\|$ Beth Levy, ${ }^{\ddagger}$ Babette Gwynn, Jeff Grubb, ${ }^{\S}$ William S. Sly, \\ and Edward H. Birkenmeier ${ }^{\|}$ \\ *The Division of Bone Marrow Transplantation and Stem Cell Biology, Department of Internal Medicine and Department of Genetics, \\ Washington University School of Medicine, St. Louis, Missouri 63110; ${ }^{\ddagger}$ The Department of Pathology, ${ }^{\S}$ The Edward A. Doisy Department \\ of Biochemistry and Molecular Biology, St. Louis University School of Medicine, St. Louis, Missouri 63104; and $\|_{\text {The Jackson }}$ \\ Laboratory, Bar Harbor, Maine 04609
}

\begin{abstract}
We demonstrated previously that short term administration of recombinant $\beta$-glucuronidase to newborn mice with mucopolysaccharidosis type VII reduced lysosomal storage in many tissues. Lysosomal storage accumulated gradually after cessation of enzyme replacement therapy. Mice alive at 1 yr of age had decreased bone deformities and less lysosomal storage in cortical neurons. Here we compare the effects of long term enzyme replacement initiated either at birth or at 6 wk of age, and of enzyme administration initiated at birth followed by syngeneic bone marrow transplantation (BMT) at $5 \mathrm{wk}$ of age. Several mice from each treatment group lived to at least $1 \mathrm{yr}$ of age. Liver and spleen samples had $\beta$-glucuronidase levels ranging from 2.4 to $19.8 \%$ of normal and showed a parallel decrease in lysosomal storage. The combination of enzyme replacement therapy followed by BMT reduced lysosomal distension in meninges, corneal fibroblasts, and bone when compared with treatment with enzyme alone. Mice treated at birth had less lysosomal storage in some neurons of the brain and the skeletal dysplasia was less severe when compared to mice whose treatment was delayed until 6 wk of age. We conclude that both enzyme replacement alone and early enzyme replacement followed by BMT have long term positive effects on murine mucopolysaccharidosis type VII. In addition, treatment started at birth is far more effective than treatment initiated in young adults. (J. Clin. Invest. 1997. 1596-1605.) Key words: $\beta$-glucuronidase $\bullet$ Sly syndrome $\bullet$ animal models $\bullet$ lysosomal storage diseases $\bullet$ central nervous system
\end{abstract}

\section{Introduction}

Lysosomal storage diseases are heritable disorders that result from the lack of specific acid hydrolases and occur with a combined frequency of 1 in 1,500 live births (1). The mucopolysac-

Address correspondence to M.S. Sands, Washington University School of Medicine, Division of Bone Marrow Transplantation and Stem Cell Biology, P.O. Box 8007, 660 South Euclid Avenue, St. Louis, MO 63110. Phone: 314-362-5494; FAX: 314-362-9333; E-mail: msands@imgate.wustl.edu

Received for publication 20 March 1996 and accepted in revised form 23 December 1996.

J. Clin. Invest.

(C) The American Society for Clinical Investigation, Inc.

0021-9738/97/04/1596/10 \$2.00

Volume 99, Number 7, April 1997, 1596-1605 charidoses, a subset of lysosomal storage diseases, are caused by the lack of one of the lysosomal enzymes responsible for the degradation of complex glycosaminoglycans. Mucopolysaccharidosis type VII (MPS VII ${ }^{1}$, Sly syndrome) is caused by a deficiency of $\beta$-glucuronidase which leads to an accumulation of undegraded heparan sulfate, chondroitin sulfate, and dermatan sulfate within the lysosomes of many cell types (2). MPS VII is characterized pathologically by distended lysosomes in the cells of many tissues, and clinically by bone and joint abnormalities, mental retardation, and a shortened life span. Murine and canine models that share many of the biochemical and pathological characteristics of human MPS VII have been described (3-5).

Murine MPS VII is an autosomal recessive disease caused by a single base pair deletion in exon 10 of the $\beta$-glucuronidase structural gene $(3,6)$. Mice homozygous for the mutation are a useful model to test the efficacy of novel therapeutic strategies for lysosomal storage diseases (3). Syngeneic bone marrow transplantation (BMT) in adult MPS VII mice effectively reversed the disease in many tissues and dramatically extended the life span (7). However, BMT performed in adult animals did not correct the defects in neurons of the central nervous system or in the skeletal system. BMT performed in neonates, which show minimal histological evidence of lysosomal storage, resulted in a dramatic improvement in the development of the skeletal system and had a persistent positive effect on auditory function and histopathology (8-10). However, we were unable to demonstrate any neurological or behavioral improvements $(8,11)$. In addition, the conditioning radiation required before BMT produced central nervous system dysplasia (8).

Results from BMT experiments suggested that the hematopoietic system might be an appropriate target for somatic cell gene therapy. To test this hypothesis, pluripotent hematopoietic stem cells from MPS VII donors were transduced with recombinant retroviruses coding for rat or human $\beta$-glucuronidase and used as donor cells for BMT. After conditioning radiation and transplantation of the genetically modified bone marrow cells, $\beta$-glucuronidase-positive cells were detected and lysosomal storage was reduced in the livers and spleens of MPS VII recipients $(12,13)$. As another approach to gene therapy, artificial organoids containing genetically modified MPS VII fibroblasts were implanted into the peritoneum of mutant mice. These organoids secreted $\beta$-glucuronidase for up to $5 \mathrm{mo}$ in quantities sufficient to reverse the disease in the liver and spleen $(14,15)$.

1. Abbreviations used in this paper: BMT, bone marrow transplantation; ER, enzyme replacement; MPS VII, mucopolysaccharidosis type VII. 
The experimental therapies described above, although promising, require surgery or a conditioning regimen such as radiation or cytotoxic drugs. Direct intravenous administration of recombinant $\beta$-glucuronidase might provide an effective, noninvasive alternative. Recently, a method was developed to produce relatively large quantities of recombinant $\beta$-glucuronidase containing both the mannose and mannose-6-phosphate recognition moieties (16). Recombinant $\beta$-glucuronidase injected intravenously into neonatal mice was rapidly cleared from the circulation and localized in many tissues expressing the mannose-6-phosphate receptor, including the central nervous system (17). The $t_{1 / 2}$ of the injected enzyme ranged from 1.2-4.2 d, depending on the tissue. At $6 \mathrm{wk}$ of age, after weekly enzyme injections starting at birth, MPS VII mice had relatively high levels of $\beta$-glucuronidase in many tissues (18). Lysosomal distension was reduced or absent in many tissues and the bones developed more normally. Remarkably, accumulation of lysosomal storage material in neurons in the brain was also reduced. When enzyme injections were stopped following this early treatment period, $\beta$-glucuronidase disappeared from the tissues and lysosomal storage reappeared in the liver and spleen by $85 \mathrm{~d}$ after the last injection (19). Although no untreated MPS VII mouse has ever lived beyond 1 yr of age (7), most of the treated mice were alive $1 \mathrm{yr}$ after the last enzyme injection and the cortical neurons had less lysosomal distension than that seen in even younger untreated MPS VII mice (19).

The present study was designed to determine the effects of long term enzyme replacement beginning either at birth or at 6 wk of age and the effect of a combination of enzyme replacement early in life followed by syngeneic BMT. One group of MPS VII mice received weekly enzyme injections starting at birth followed by monthly injections after 6 wk. A second group received monthly enzyme injections starting at $6 \mathrm{wk}$ of age. A third group received weekly enzyme injections from birth to $5 \mathrm{wk}$ of age followed by syngeneic BMT. The results indicate that all three treatment protocols have long term therapeutic effects. However, treatment with combination therapy appears to provide a more complete therapeutic response than enzyme replacement initiated at birth, which, in turn, is more effective than enzyme replacement started later in life.

\section{Methods}

Animals. Homozygous mutant (gus $s^{m p s} / g u s^{m p s}$ ) and phenotypically normal $(+/$ ? $)$ mice were obtained from B6.C- $H-2^{\text {bml }} /$ ByBir-gus ${ }^{m p s} /+$ mutant strain maintained by E.H. Birkenmeier at The Jackson Laboratory (Bar Harbor, ME) (3). Animals for this study were either from a pedigreed colony, maintained by strict brother-sister matings, or from a nonpedigreed colony, maintained by crossing heterozygous animals obtained from the pedigreed colony. The offspring were never more than one generation from the pedigreed colony. Homozygous mutants $\left(\mathrm{gus}^{\mathrm{mps}} / \mathrm{gus}^{\mathrm{mps}}\right)$ were distinguished from normals $(+/+$ or $\left.+/ g u s^{m p s}\right)$ at birth using a fluorometric assay $(20,21)$ to determine the presence or absence of $\beta$-glucuronidase activity in a sample of tissue obtained by toe clipping (8).

Enzyme production and purification. Mannose-6-phosphate receptor deficient mouse L cells (22) which secrete $\sim 70 \%$ of lysosomal enzymes with the phosphomannosyl recognition marker were stably transfected with an expression plasmid containing the mouse $\beta$-glucuronidase cDNA $(16,23)$. $\beta$-Glucuronidase was purified from the conditioned media by ammonium sulfate precipitation, sephadex, and ion exchange chromatography (16). The purified enzyme $\left(2 \times 10^{6}\right.$
$\mathrm{U} / \mathrm{mg}$ ) was diluted in $10 \mathrm{mM}$ Tris, $\mathrm{pH} 7.5,150 \mathrm{mM} \mathrm{NaCl}$, and $1 \mathrm{mM}$ $\beta$-glycerophosphate to a concentration of $2.8 \times 10^{5} \mathrm{U} / \mathrm{ml}$ and stored at $-70^{\circ} \mathrm{C}$. $\beta$-Glucuronidase activity units (U) are expressed as nanomoles of substrate hydrolyzed per hour.

Enzyme injections and treatment groups. Aliquots of enzyme were thawed and assayed immediately before injection. 21 MPS VII mice were injected on the day they were born with $28,000 \mathrm{U}$ each of recombinant $\beta$-glucuronidase into the superficial temporal vein. At $1 \mathrm{wk}$ of age they received the same dose intraperitoneally followed by four injections into the tail vein at weekly intervals. On day $36,1 \mathrm{~d}$ after the last weekly injection, 10 mice were exposed to 400 rads of $\gamma$ radiation delivered from ${ }^{137} \mathrm{Cs}$ source followed by injection of $1 \times 10^{6}$ bone marrow cells from the femurs of $+/+$ female donors. The mice receiving BMT were not injected with any additional enzyme and will be referred to as the "Combined Therapy" group. The remaining 11 mice that received enzyme injections starting at birth were given $28,000 \mathrm{U}$ of enzyme at 30-d intervals starting at $65 \mathrm{~d}$ of age and will be referred to as the "Continuous ER" group. 10 MPS VII mice received no treatment until $35 \mathrm{~d}$ of age at which time they began receiving $28,000 \mathrm{U}$ of enzyme intravenously at 30-d intervals. This group will be referred to as the "Delayed ER" group. Five phenotypically normal $(+/$ ? mice were injected intravenously with enzyme the day they were born and weekly thereafter until day 35 and then given BMT at day 36. At $185 \mathrm{~d}$ of age two mice from each treatment group were killed and analyzed histologically, histochemically, and biochemically to determine the effectiveness of the various treatments. Surviving mice were killed between 342 and $395 \mathrm{~d}$ of age and analyzed as described previously (18). The surviving experimental animals from the Continuous ER and the Delayed ER groups were killed 1 wk after the last enzyme injection. Untreated normal and MPS VII mice were identified and used as controls.

Biochemical and histochemical analysis. Tissue sections were isolated and homogenized in $20 \mathrm{mM}$ Tris, $\mathrm{pH} 7.5,140 \mathrm{mM} \mathrm{NaCl}, 10 \mathrm{mM}$ $\beta$-mercaptoethanol, and $0.25 \%$ saponin with a motorized pestle. Lysosomal enzymes were assayed fluorometrically using 4-methylumbelliferyl (4-MU) substrates $(10 \mathrm{mM})$ as previously described $(8,20$, 21). $\beta$-Glucuronidase, $\alpha$-galactosidase, and $\beta$-hexoseaminidase were assayed with the substrates 4-MU- $\beta$-D-glucuronide, $4-\mathrm{MU}-\alpha-\mathrm{D}$-galactoside, and 4-MU-N-acetyl- $\beta$-D-glucosaminide, respectively (Sigma Chemical Co., St. Louis, MO). Protein determinations were performed by the Coomassie dye binding assay (24). $\beta$-Glucuronidase was identified histochemically in frozen sections of costal marrow, liver, spleen, and brain from selected animals $\geq 342 \mathrm{~d}$ of age that received Combined Therapy, Continuous ER, and Delayed ER as previously described (25). Histochemical analysis was performed on samples of liver and spleen obtained prior to perfusion in animals killed at $185 \mathrm{~d}$ of age. Briefly, $10-\mu \mathrm{m}$ cryosections were fixed in chlorolhydrate-formalin-acetone fixative for $20-30 \mathrm{~min}$ at $4^{\circ} \mathrm{C}$, washed, then incubated for $2-4 \mathrm{~h}$ in $0.25 \mathrm{mM}$ naphthol-AS-BI- $\beta$-D-glucuronide (Sigma Chemical Co.) in $50 \mathrm{mM}$ sodium acetate buffer, $\mathrm{pH}$ 4.5. The sections were then stained in $0.25 \mathrm{mM}$ naphthol-AS-BI- $\beta-D-$ glucuronide and pararosaniline hydrochloride for $16 \mathrm{~h}$ at $37^{\circ} \mathrm{C}$. Histochemically stained sections were then counter stained with $1 \%$ methyl green for $10 \mathrm{~min}$.

Pathology. Tissues were collected, fixed, and prepared for light and electron microscopy as previously described $(4,19)$. The two animals killed at $185 \mathrm{~d}$ of age from each group were anesthetized and perfused through the left ventricle with $2 \%$ glutaraldehyde, $4 \%$ paraformaldehyde in phosphate buffered saline. Before perfusion, liver and spleen biopsies were obtained for histochemical and biochemical analysis. Animals $\geq 342 \mathrm{~d}$ of age from the Combined Therapy $(n=4)$, Continuous ER $(n=3)$, and Delayed ER $(n=5)$ groups were examined histologically for the presence or absence of lysosomal distention. For histology, toluidine blue-stained, $0.5-\mu \mathrm{m}$ thick sections of tissue embedded in Spurr's resin were evaluated for lysosomal storage. Without knowledge of the therapeutic regimen with which specific animals were treated, tissues were evaluated with those from other ongoing studies using a semiquantitative scale. When stor- 
age was very difficult to find in many areas or was not apparent by light microscopy, i.e., nearly complete clearance of storage, "marked reduction" in lysosomal storage was scored. "Moderate reduction" in storage was identified when lysosomal distention was present but was generally reduced compared with untreated MPS VII controls. A slight and focal reduction in storage compared with untreated MPS VII controls was scored as "focal reduction". To receive an assessment of focal reduction, storage was more apparent than if a score of moderate reduction was assigned. These assessments were made by histological study of the entire tissue sample section for each organ except the brain. For the brain, two transverse sections, one at the level of the hippocampus and including the temporal cortex, and the other at the level of the brain stem and cerebellum were examined by two pathologists. Tissue from age-matched, untreated MPS VII animals were used as controls. Since untreated MPS VII mice do not generally survive past $300 \mathrm{~d}$ of age, a 185-d-old control and untreated MPS VII mice older than $200 \mathrm{~d}$ from previous experiments were used for comparison with the treated animals older than $300 \mathrm{~d}$.

Morphometric analyses were performed on the femur, humerus, radius, ulna, tibia, and fibula from treated and untreated mice as previously described (8). Bone lengths were grouped and compared according to treatment and sex.

Enzyme-linked immunosorbent assay and immunoprecipitation. An ELISA was performed on plasma from treated and untreated mice to detect antibodies against antigens present in the recombinant $\beta$-glucuronidase preparations. Purified recombinant murine $\beta$-glucuronidase at $10 \mu \mathrm{g} / \mathrm{ml}$ in $15 \mathrm{mM} \mathrm{Na}_{2} \mathrm{CO}_{3}, 35 \mathrm{mM} \mathrm{NaHCO}, 0.02 \%$ $\mathrm{NaN}_{3}$ (pH 9.6) was incubated overnight in 96-well microtiter plates. The wells were washed three times with TBST (10 mM Tris [pH 7.5], $150 \mathrm{mM} \mathrm{NaCl}, 0.05 \%$ Tween 20 ), then blocked for $1 \mathrm{~h}$ at $25^{\circ} \mathrm{C}$ with $3 \%$ casein in PBS. Dilutions of mouse plasma in TBST $(100 \mu l$ at $10^{-2}, 10^{-3}$, and $10^{-4}$ dilution) were added to the wells and incubated at $37^{\circ} \mathrm{C}$ for $2.5 \mathrm{~h}$. The wells were washed $4 \times$ with TBST, then $100 \mu \mathrm{l}$ of TBST containing a 1/500 dilution of peroxidase conjugated goat anti-mouse IgG (Sigma Chemical Co.) was added and incubated at $25^{\circ} \mathrm{C}$ for $1 \mathrm{~h}$. The wells were then washed three times with TBST and two times with TBS (10 mM Tris [pH 7.5], $150 \mathrm{mM} \mathrm{NaCl}) .100 \mu \mathrm{l}$ of ABTS peroxidase substrate $(0.1 \mathrm{mg} / \mathrm{ml}$ ABTS [azinobis $\{3$-ethylbenzothiazoline-6-sulfonic acid\} diammonium salt] [Boehringer Mannheim, Indianapolis, IN], $24 \mathrm{mM}$ citric acid, $52 \mathrm{mM} \mathrm{Na}_{2} \mathrm{HPO}_{4}[\mathrm{pH} 5.0]+$ $0.5 \mu \mathrm{l} 30 \% \mathrm{H}_{2} \mathrm{O}_{2}$ ) were added per well and incubated at room temperature for $30 \mathrm{~min}$. The absorbance at $405 \mathrm{~nm}$ was determined on an automatic ELISA plate reader (Molecular Devices, Sunnyvale, CA).

An immunoprecipitation assay was used to detect antibodies directed against murine $\beta$-glucuronidase in the plasma from treated and untreated mice. This assay is based on the ability to recover $\beta$-glucuronidase activity in the pellet fraction, and lose enzyme activity from solution after precipitation of antibody- $\beta$-glucuronidase complexes with protein $\mathrm{G}$-sepharose. Murine $\beta$-glucuronidase $(500 \mathrm{U})$ was added to $1 \mathrm{ml}$ of PBS containing $10 \mu \mathrm{l}$ of mouse plasma and $1 \mathrm{mg} / \mathrm{ml}$ BSA. The solution was incubated overnight at $4^{\circ} \mathrm{C}$ on a rotating wheel then $100 \mu \mathrm{l}$ of a 1:1 mixture of protein G-sepharose (Pharmacia LKB Biotechnology, Piscataway, NJ) in PBS was added and mixed at $4^{\circ} \mathrm{C}$ for $4 \mathrm{~h}$. The complexes were pelleted in a microcentrifuge for 2 min at 14,000 rpm. The supernatant was collected and the pellet was washed twice with $1 \mathrm{ml}$ PBS. The pellets were resuspended in $0.5 \mathrm{ml}$ PBS containing $1 \mathrm{mg} / \mathrm{ml}$ BSA. Supernatants and resuspended pellets were assayed fluorometrically for $\beta$-glucuronidase activity $(8,20,21)$. Units were expressed as nanomoles substrate hydrolyzed/hour. Reactions containing no antibody or $2.5 \mu \mathrm{l}$ of polyclonal goat anti-mouse $\beta$-glucuronidase antibody were performed as negative and positive controls, respectively.

Statistical analysis. All biochemical and morphometric comparisons are represented as percentages of untreated normal mice and analyzed for statistical significance using Student's $t$ test. Survival in the untreated MPS VII mice and in the groups of mice receiving the various treatments was analyzed by the Kaplan-Meier method (26). The groups were compared using Log-Rank analysis.

\section{Results}

Biochemical response to Combined Therapy, Continuous ER and Delayed ER. Two groups of MPS VII mice received enzyme replacement therapy (ER) only; one, starting at birth, is referred to as the Continuous ER group, and a second, starting at 6 wk of age, is referred to as the Delayed ER group. A third group of MPS VII mice received early enzyme injections (from birth to $5 \mathrm{wk}$ of age) followed by BMT at $5 \mathrm{wk}$ of age, and is referred to as the Combined Therapy group. The data summarized in Fig. 1 show that the level of $\beta$-glucuronidase activity 1 wk after the last injection was similar in both the Continuous ER and the Delayed ER groups. The level of enzyme activity was $\sim 18.5,3.0,0.5$, and $0.25 \%$ normal in liver, spleen, kidney, and brain, respectively. These levels are comparable to those previously observed in MPS VII mice that received enzyme injections from birth to $5 \mathrm{wk}$ of age (18). The data in Fig. 1 also show that $\beta$-glucuronidase levels and distribution were different in the Combined Therapy group compared with either the Continuous ER or the Delayed ER groups. However, the distribution and level of $\beta$-glucuronidase in the Combined Therapy group was similar to that previously observed in MPS VII mice treated with BMT alone $(7,8)$. The liver, spleen, kidney, and brain in the animals receiving the Combined Therapy had $5.5,19.8,0.77$, and $0.75 \%$ normal levels, respectively. $\beta$-Glucuronidase activity in the brains of these mice was significantly higher than in the brains of untreated MPS VII mice $(P<$ 0.001) or those of MPS VII mice in either the Continuous ER or the Delayed ER groups $(P<0.02)$.

Reductions in the secondary elevations of the lysosomal enzymes $\alpha$-galactosidase and $\beta$-hexoseaminidase have been shown to provide biochemical indicators of a positive therapeutic response in murine MPS VII $(7,8,12,18)$. Fig. 2 shows that, in all three treatment groups, the secondary elevations of both lysosomal enzymes were reduced in the livers, spleens, and kidneys when compared with the levels seen in organs from untreated MPS VII mice. The decreases in secondary ele-

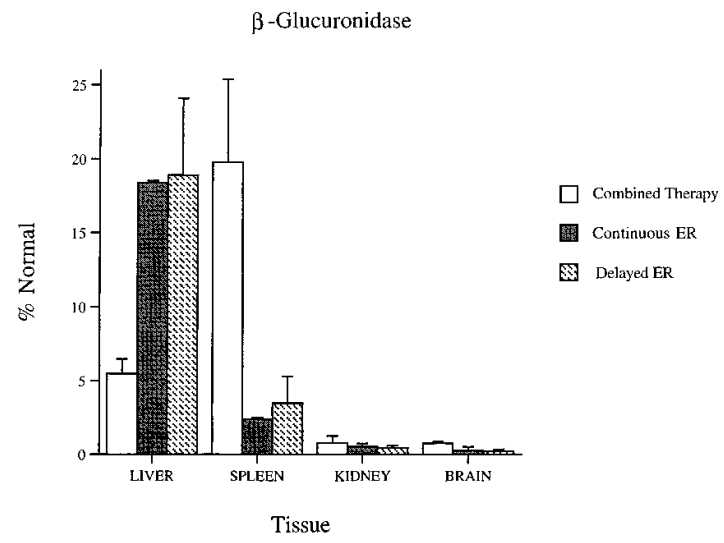

Figure 1. $\beta$-Glucuronidase activity in the liver, spleen, kidney, and brain from $\geq 342$-d-old MPS VII mice receiving the Combined Therapy, Continuous ER, or Delayed ER protocols (see Methods). The enzyme activity is expressed as percentage of normal $(+/+)$. Error bars represent one standard deviation from the mean. $\beta$-Glucuronidase activity in the liver, spleen, kidney, and brain was $0.03,0.01$, 0.01 , and $0.07 \%$ normal, respectively, in untreated MPS VII mice $(n=3)$ ranging from 3 to 6 mo of age. 
A

$\alpha-$ Galactosidase

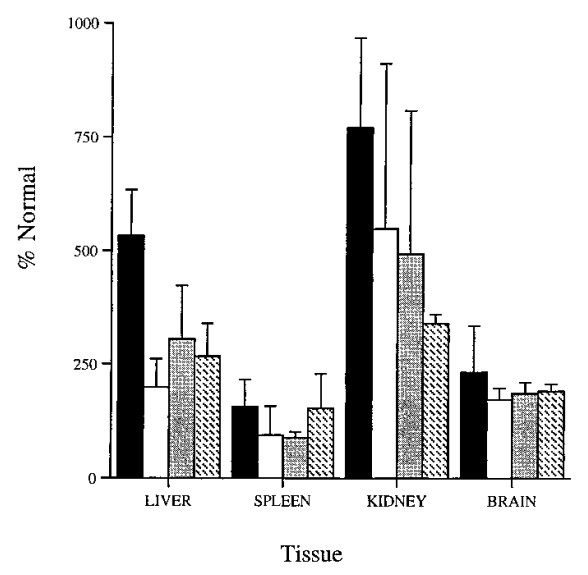

B

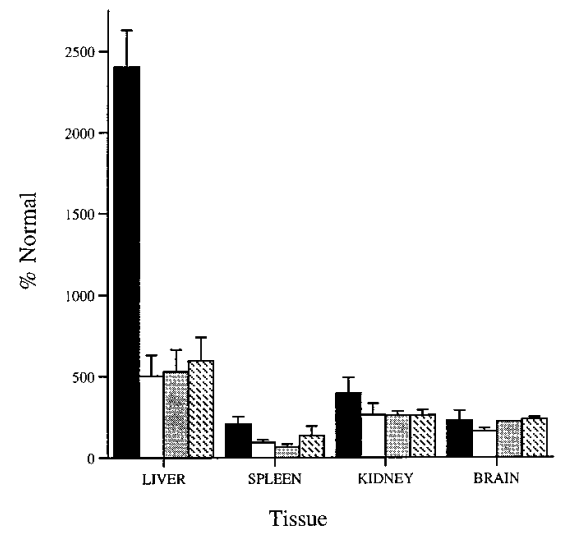

Untreated MPS VI

$\square$ Combined Therapy

Continuous ER

图 Delayed ER

Figure 2. Secondary elevations of the lysosomal enzymes $\alpha$-galactosidase $(A)$ and $\beta$-hexoseaminidase $(B)$ are shown in the same tissues as described in Fig. 1. The activity is expressed as a percentage of $+/+$ activity and the error bars represent one standard deviation from the mean.

vations in the brain were most pronounced in the group of animals receiving the Combined Therapy. $\beta$-Hexoseaminidase activity was significantly $(P<0.05)$ lower in the brains of the Combined Therapy group than in either the Continuous ER or the Delayed ER groups. Although the $\alpha$-galactosidase activity in the brains of mice receiving Combined Therapy was lower, on average, than that observed in the brains of untreated MPS VII mice, the difference was not statistically significant. There was no statistically significant difference in the secondary elevations of $\alpha$-galactosidase and $\beta$-hexoseaminidase in the brains of the Continuous ER and the Delayed ER groups when compared with levels in untreated MPS VII mice. Although some of the decreases in the secondary elevations in the brains of the treated animals were statistically significant, the decreases were small and it is not clear whether these decreases are biologically significant.

Histochemical analysis of tissues from animals treated with either Continuous ER or Delayed ER showed $\beta$-glucuronidase activity in hepatocytes, liver sinus lining cells, and spleen red pulp (data not shown). In MPS VII mice $\geq 342 \mathrm{~d}$ of age which received Combined Therapy, $\beta$-glucuronidase activity

Table I. Average Long Bone Lengths and Body Weights of Treated and Untreated MPS VII and Normal Mice Expressed as Percent of Normal (+/?) and One Standard Deviation from the Mean (SD)

\begin{tabular}{|c|c|c|c|c|}
\hline \multirow[b]{2}{*}{ Treatment group $\$$} & \multicolumn{2}{|c|}{ Bone lengths* } & \multicolumn{2}{|c|}{ Body weight ${ }^{\ddagger}$} \\
\hline & $\%+/ ?$ & SD & $\%+/ ?$ & SD \\
\hline Normal untreated & 100 & $3.7(n=19)$ & 100 & $3.8(n=10)$ \\
\hline MPS VII untreated & $85.2^{\|}$ & $3.9(n=10)$ & $67.4^{\pi}$ & $11.7(n=8)$ \\
\hline Combined therapy & 93.6 & $2.5(n=6)$ & 77.9 & $7.9(n=3)$ \\
\hline Continuous ER & 91.9 & $3.6(n=8)$ & 92.7 & $6.4(n=3)$ \\
\hline Delayed ER & 89.1 & $2.8(n=6)$ & 66.9 & $11.8(n=5)$ \\
\hline Normal combined therapy & 100 & $6.8(n=7)$ & 96.5 & $7.0(n=5)$ \\
\hline
\end{tabular}

*Treated normal and MPS VII and untreated normal mice included in the measurements of bone lengths ranged in age from 65 to $393 \mathrm{~d}$. ¥Treated normal and MPS VII and untreated normal mice ranging from 342 to 393 days of age were included in the measurements for body weight. ${ }^{\S}$ The treatment groups are as follows: +/?, untreated phenotypically normal mice of the same strain; MPS VII, untreated gus $^{m p s} / g_{u s} s^{m p s}$ mice; the remaining groups are descibed in Methods and Results. "Untreated MPS VII animals ranging in age from 67 to $218 \mathrm{~d}$ were included in the measurements of bone length. "The percentage of normal body weight for untreated MPS VII mice was determined on mice ranging in age from 73 to 196 days of age. The percent normal was calculated for individual MPS VII mice compared to sex-matched untreated normal littermates. The percents were then averaged and a standard deviation calculated.

was present in the bone marrow, liver sinus lining cells, spleen red pulp, and white pulp. One of the oldest survivors in the Combined Therapy group had $\beta$-glucuronidase-containing cells in the meninges and isolated positive cells in the brain.

Phenotypic correction of murine MPS VII after Combined Therapy and Continuous ER. Clinically, the MPS VII mice in the two groups receiving Combined Therapy or Continuous ER were difficult to distinguish from normal mice as they approached $1 \mathrm{yr}$ of age. In contrast, mice in the Delayed ER group already displayed the characteristic MPS VII phenotype at the onset of therapy (skeletal dysplasia with stunted growth and abnormal facies) and showed no phenotypic improvement after enzyme injections for 10 mo. Both groups receiving Combined Therapy or Continuous ER had significant increases $(P<0.01)$ in adult bone length compared to untreated MPS VII mice (Table I). Even the mice in the Delayed ER group showed a significant increase $(P<0.05)$ in bone length over those of untreated MPS VII mice. There was no significant difference between the bone lengths at $1 \mathrm{yr}$ of age from the group of mice which received Continuous ER and those from a prior study which received enzyme starting at birth with no additional injections past $5 \mathrm{wk}$ of age (19). However, the group that received Combined Therapy showed a significant increase $(P<0.05)$ in the bone lengths compared to that previously reported group receiving enzyme alone during the neonatal period (19).

Table I also presents body weight comparisons between the treatment groups. The body weights of animals which received Continuous ER were close to normal at nearly $1 \mathrm{yr}$ of age. The body weights of MPS VII mice which received Combined Therapy were significantly less than normal. However, the 


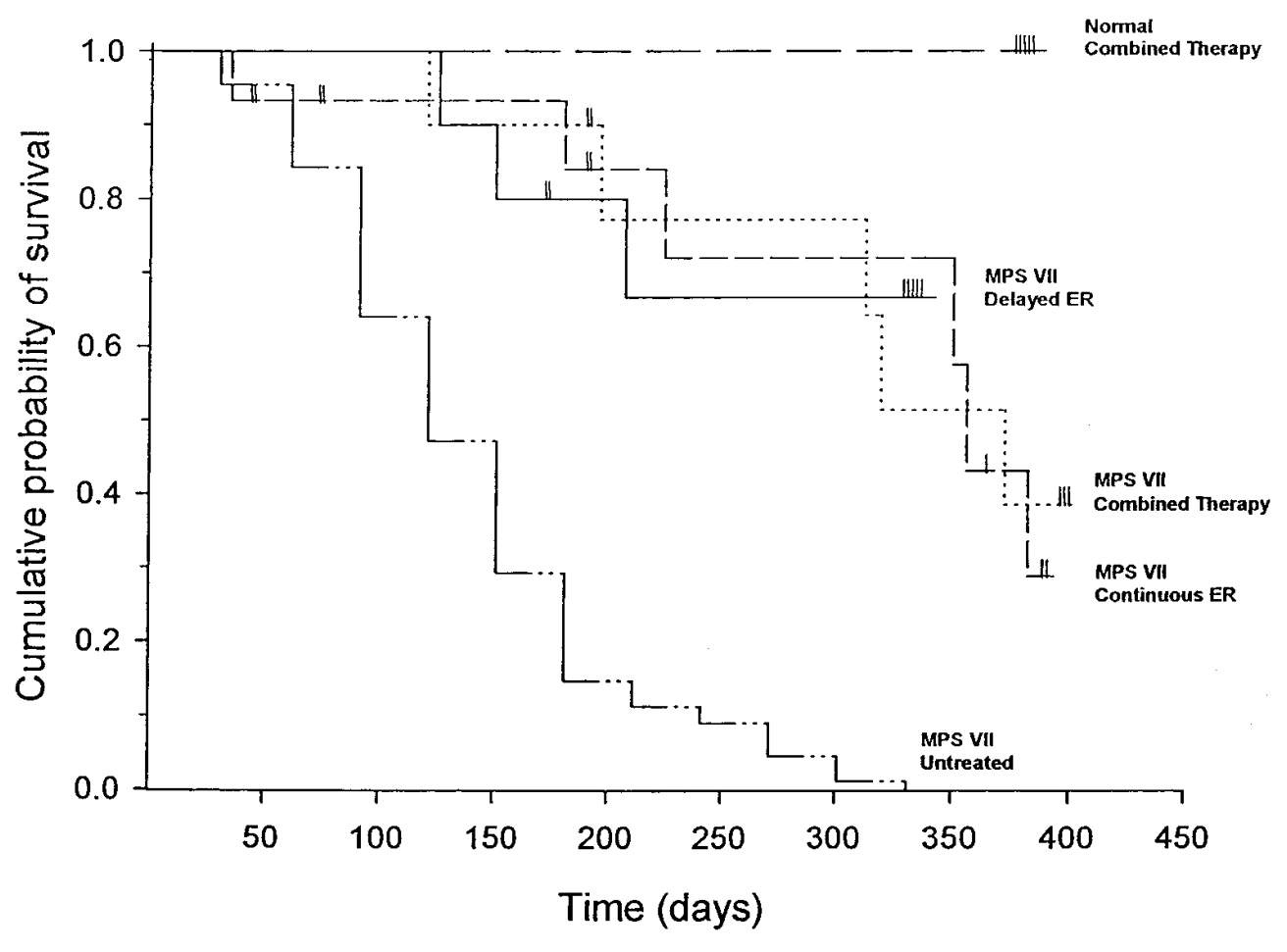

Figure 3. Probability of survival of treated and untreated MPS VII mice (historical controls) and treated normal mice. The probabilities that MPS VII mice will survive to at least $342 \mathrm{~d}$ of age following Combined Therapy, Continuous ER, and Delayed ER are 39, 29, and 67\%, respectively. All three groups of treated MPS VII mice had a statistically significant $(P<0.001)$ increase in life span compared with untreated MPS VII mice. Vertical tick marks on the respective curves represent animals that were removed from the study for biochemical, histochemical, and histopathological analysis. The study was terminated when all the mice were at least $342 \mathrm{~d}$ of age. body weights were significantly greater $(P<0.001)$ than those of MPS VII mice which received Delayed ER.

Fig. 3 summarizes the survival data from the four treatment groups in this study, and presents data on untreated MPS VII animals from a prior study (7). The normal control animals that received Combined Therapy showed no mortality $>1 \mathrm{yr}$. Untreated MPS VII mice, from prior studies, were all dead by $1 \mathrm{yr}$ of age, and $50 \%$ were dead by $150 \mathrm{~d}$. All three groups of treated MPS VII animals had a significantly $(P<0.001)$ increased life span compared with the untreated MPS VII mice. There was no statistically significant difference between the life spans of the three groups of treated MPS VII mice.

Histopathologic evidence of reduced lysosomal storage. In all three treatment groups, animals had reduced lysosomal storage in Kupffer cells of the liver and in the sinus lining cells and trabecular cells of the spleen (Table II). The osteoblasts lining bone trabeculae and osteocytes within the trabeculae showed reduced lysosomal storage material in animals from all three treatment groups at nearly $1 \mathrm{yr}$ of age (Fig. 4). There was a marked decrease in lysosomal storage in the corneal fibroblasts of mice treated with Combined Therapy (Fig. 5). In contrast, the corneal fibroblasts of MPS VII mice treated with either Continuous ER or Delayed ER showed no reduction in lysosomal storage.

Meningeal storage was reduced in all the groups when compared with untreated MPS VII mice (Fig. 6). Improvement in the leptomeninges was greatest in MPS VII mice which received Combined Therapy. Neocortical neurons in MPS VII mice in each treatment group had a slight or moderate decrease in lysosomal storage material (Fig. 7). Hippocampal cortical neurons in mice from the Combined Therapy and Continuous ER groups also had a slight decrease in lysosomal distension at $185 \mathrm{~d}$ of age but, by $\geq 342$ days of age, these neurons were indistinguishable from those in untreated MPS VII mice. In mice treated with Delayed ER, hippocampal neurons showed no response to treatment. Glial and Purkinje cell cytoplasmic vacuolation was not reduced in any of the treatment groups. The cerebellar dysplasia observed in MPS VII mice irradiated at birth before BMT (8) was not seen in any of the treatment groups in this study, including those which received the Combined Therapy.

Adverse reactions to enzyme replacement therapy. MPS VII mice which received six weekly injections of enzyme starting at birth in this study and prior studies $(18,19)$ showed no obvious adverse reactions during the first 6 wk of life. However, 5 of the 10 animals in the Continuous ER group had mild to severe reactions later; the earliest reactions occurred at $65 \mathrm{~d}$ of age. The reactions occurred immediately after the injections, lasted 15-30 min, and were characterized by labored breathing and lethargy. One mouse in the Continuous ER group died $1 \mathrm{~h}$ after an enzyme injection. Some of the MPS VII mice in the Delayed ER group also had similar adverse reactions. One mouse in this group died at $121 \mathrm{~d}$ of age immediately after the third enzyme injection. After the reactions were observed, all the mice that received monthly enzyme injections were injected intraperitoneally with $0.2 \mathrm{mg} / \mathrm{kg}$ dexamethasone $24 \mathrm{~h}$ before their enzyme injections, and again $1 \mathrm{~h}$ before the enzyme injections with $0.2 \mathrm{mg} / \mathrm{kg}$ dexamethasone, $1 \mathrm{mg} / \mathrm{kg}$ diphenhydrazine, and $0.5 \mathrm{mg} / \mathrm{kg}$ ephedrine. This treatment appeared to delay the onset and perhaps decrease the severity of reactions after injection but did not prevent their occurrence in animals that had previously had reactions following injections.

At the end of the study, serum was analyzed by ELISA for the presence of antibodies against an antigen in the enzyme preparation and by immunoprecipitation for the presence of specific antibodies against murine $\beta$-glucuronidase. All of the animals from the Continuous ER and Delayed ER groups had measurable levels of antibodies against an antigen in the enzyme preparation. However, antibodies from the same sera, 
Table II. Reduction in Lysosomal Storage after Long Term Enzyme Replacement Alone or a Combination of Enzyme Replacement followed by BMT*

\begin{tabular}{|c|c|c|c|}
\hline \multirow[b]{2}{*}{ Tissue } & \multicolumn{3}{|c|}{ Treatment } \\
\hline & Continuous ER & Delayed ER & Combined therapy \\
\hline Spleen $(\mathrm{N})$ & (5) & (7) & (6) \\
\hline Sinus lining cells & Mod-Mkd & Mod-Mkd & Mkd \\
\hline Trabecular fibroblasts & Mod-Mkd & Mkd & Mod \\
\hline Liver (N) & (5) & (7) & (6) \\
\hline Sinus lining cells & Mod-Mkd & Mod-Mkd & Mod-Mkd \\
\hline Bone $(\mathrm{N})$ & (5) & (7) & (4) \\
\hline Osteoblasts & Foc-Mod & Foc-Mod & Mod-Mkd \\
\hline Osteocytes & Foc-Mod & Foc-Mod & Mod-Mkd \\
\hline Marrow sinus lining cells & Foc-Mkd & Mod-Mkd & Mkd \\
\hline Marrow cells & Foc-Mkd & Mod-Mkd & Mod-Mkd \\
\hline Chondrocytes & $\mathrm{NC}$ & $\mathrm{NC}$ & $\mathrm{NC}$ \\
\hline Brain (N) & (5) & (7) & (5) \\
\hline Meninges & Mod & Foc-Mod & Mkd \\
\hline Cortical neurons & Foc-Mod & Foc-Mod & Foc-Mod \\
\hline Hippocampal neurons & Foc & $\mathrm{NC}$ & Foc \\
\hline Purkinje cells & $\mathrm{NC}$ & $\mathrm{NC}$ & $\mathrm{NC}$ \\
\hline Glial cells & $\mathrm{NC}$ & $\mathrm{NC}$ & $\mathrm{NC}$ \\
\hline Eye (N) & (3) & (5) & (4) \\
\hline Cornea & $\mathrm{NC}$ & $\mathrm{NC}$ & Mkd \\
\hline $\begin{array}{l}\text { Retinal pigment } \\
\text { epithelium }\end{array}$ & Foc & Foc & Mod-Mkd \\
\hline
\end{tabular}

$M k d$, marked - nearly complete clearance of lysosomal storage; Mod, moderate - general reduction in lysosomal storage; Foc, focal - slight and focal reduction in lysosomal storage; ranges indicate variation among animals in groups. $(N)$ : Number of animals examined histologically; data from 185-d-old and over 342-d-old MPS VII mice combined to show range in reduction in lysosomal storage. $N C$, no change compared to untreated MPSV II mice.

bound to protein G-Sepharose failed to precipitate purified murine $\beta$-glucuronidase. This suggests that the mice developed antibodies against a contaminant in the enzyme preparation but not specifically to the $\beta$-glucuronidase. A likely candidate for the antigenic contaminant is human serum albumin (HSA). HSA was added to the enzyme preparation at an early stage of purification to enhance enzyme stability. The sera described above demonstrated very low or undetectable levels of antibodies against a preparation of recombinant $\beta$-glucuronidase purified in the absence of HSA but did react in Western blots with purified HSA (data not shown).

No antibodies against any antigen in the enzyme preparation were detected in the sera from mice which received the Combined Therapy. However, one animal in the Combined Therapy group was killed at $121 \mathrm{~d}$ of age due to severe dermatitis and another mouse in the same group was killed at $373 \mathrm{~d}$ of age due to lymphoma.

\section{Discussion}

We recently reported that injections of recombinant murine $\beta$-glucuronidase during the first $5 \mathrm{wk}$ of life led to a striking re-
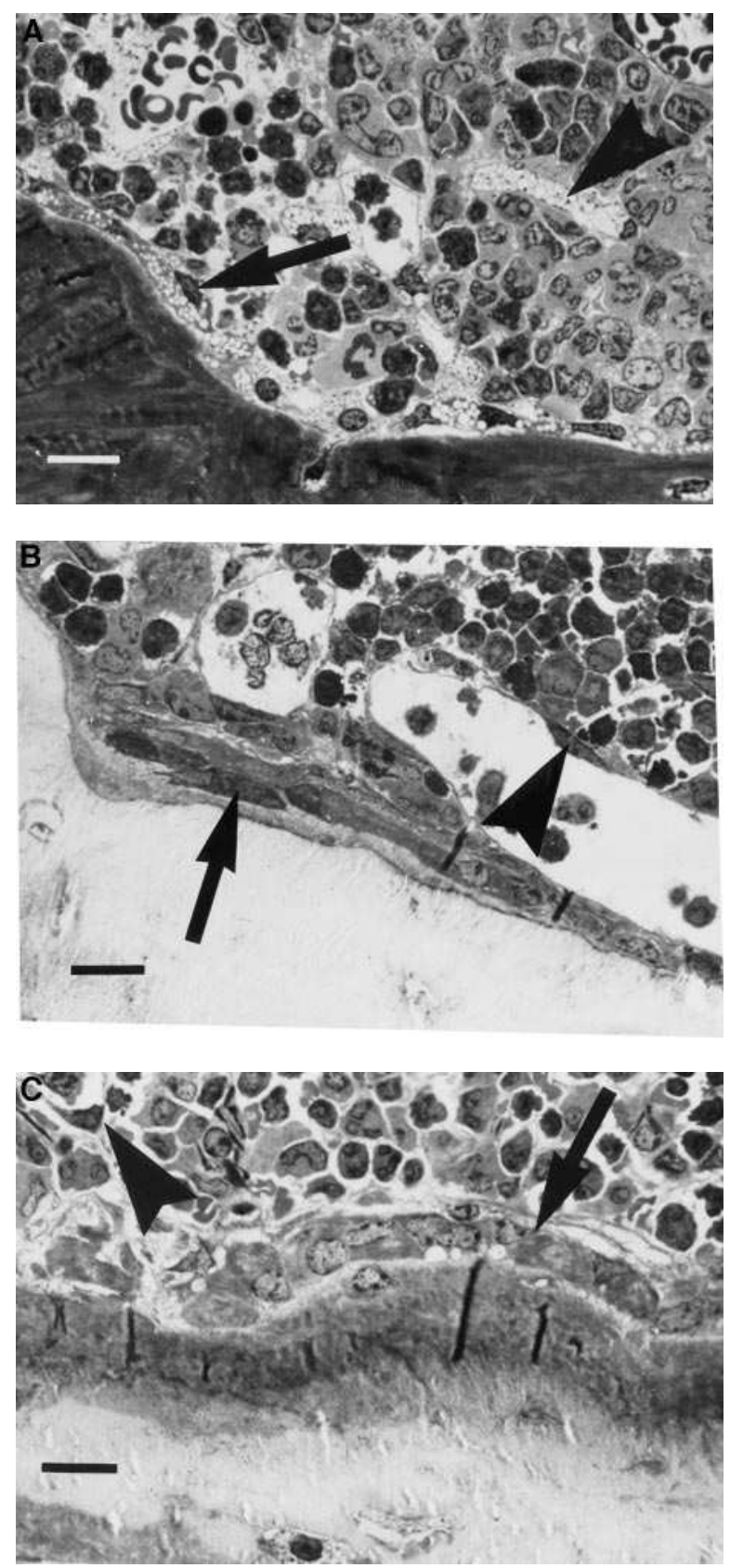

Figure 4. Abundant cytoplasmic vacuolation is observed in the osteoblasts (arrows) lining the bone trabeculae and cortical bone as well as in the sinus lining cells (arrowheads) in an untreated MPS VII mouse $(A)$. Both cell types responded to Continuous ER $(B)$ and Combined Therapy $(C) .(A-C$ : toluidine blue, bar $=15 \mu \mathrm{m})$.

duction of lysosomal storage material in many tissues, including neurons of the CNS, and resulted in an increased life span (17-19). We demonstrate here that monthly enzyme replacement beyond the first $5 \mathrm{wk}$ of life resulted in a persistent therapeutic response as indicated by decreased lysosomal storage in the liver, spleen, bone, meninges, and cortical neurons. The treated MPS VII mice also had decreased bone dysplasia as reflected by more normal bone growth even when the therapy was initiated at $5 \mathrm{wk}$ of age (Delayed ER).

The persistent reduction in lysosomal storage in the corti- 

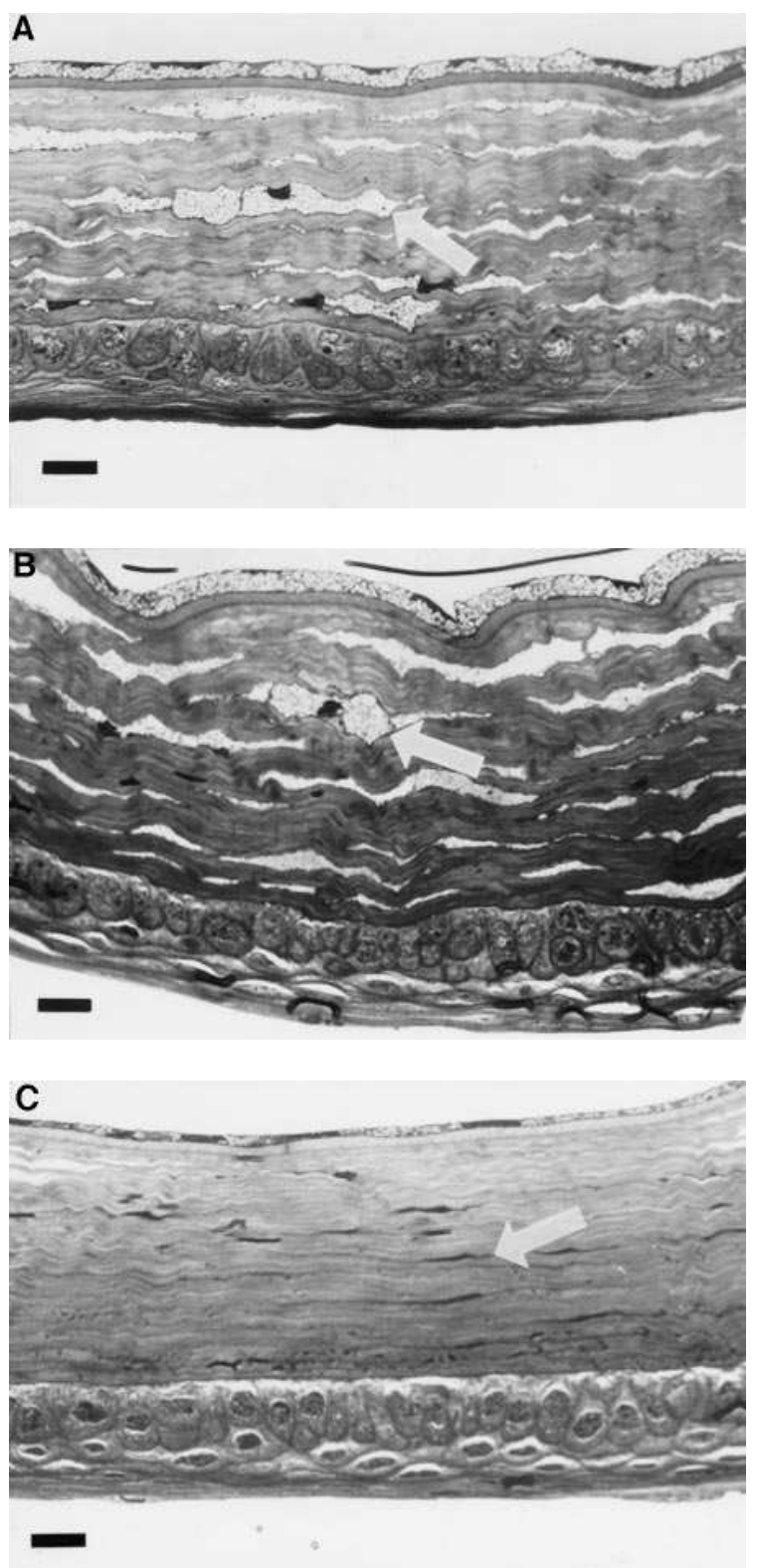

Figure 5. Corneal fibroblasts (arrows) in an untreated MPS VII mouse $(A)$ and a mouse receiving continuous ER $(B)$ have extensive cytoplasmic vacuolization. An MPS VII mouse treated with Combined Therapy $(C)$ has much less storage material than that seen in either of the other animals. $(A-C$ : toluidine blue, bar $=10 \mu \mathrm{m})$.

cal neurons is of interest. Perhaps, the requirement for $\beta$-glucuronidase for glycosaminoglycan metabolism is greatest in the CNS during the neonatal period when neuronal migration and remodelling are taking place. Therefore, if the accumulation of lysosomal storage material can be prevented in neurons during neonatal development (18), persistent low levels of $\beta$-glucuronidase in the CNS following enzyme therapy or BMT may be sufficient to prevent accumulation of lysosomal storage material for an extended period of time.

The Delayed ER group showed no decrease in lysosomal storage in the hippocampal neurons of the CNS at 185 or $>342 \mathrm{~d}$ of age. In contrast, when the therapy was initiated at birth (Combined Therapy and Continuous ER) the lysosomal dis-
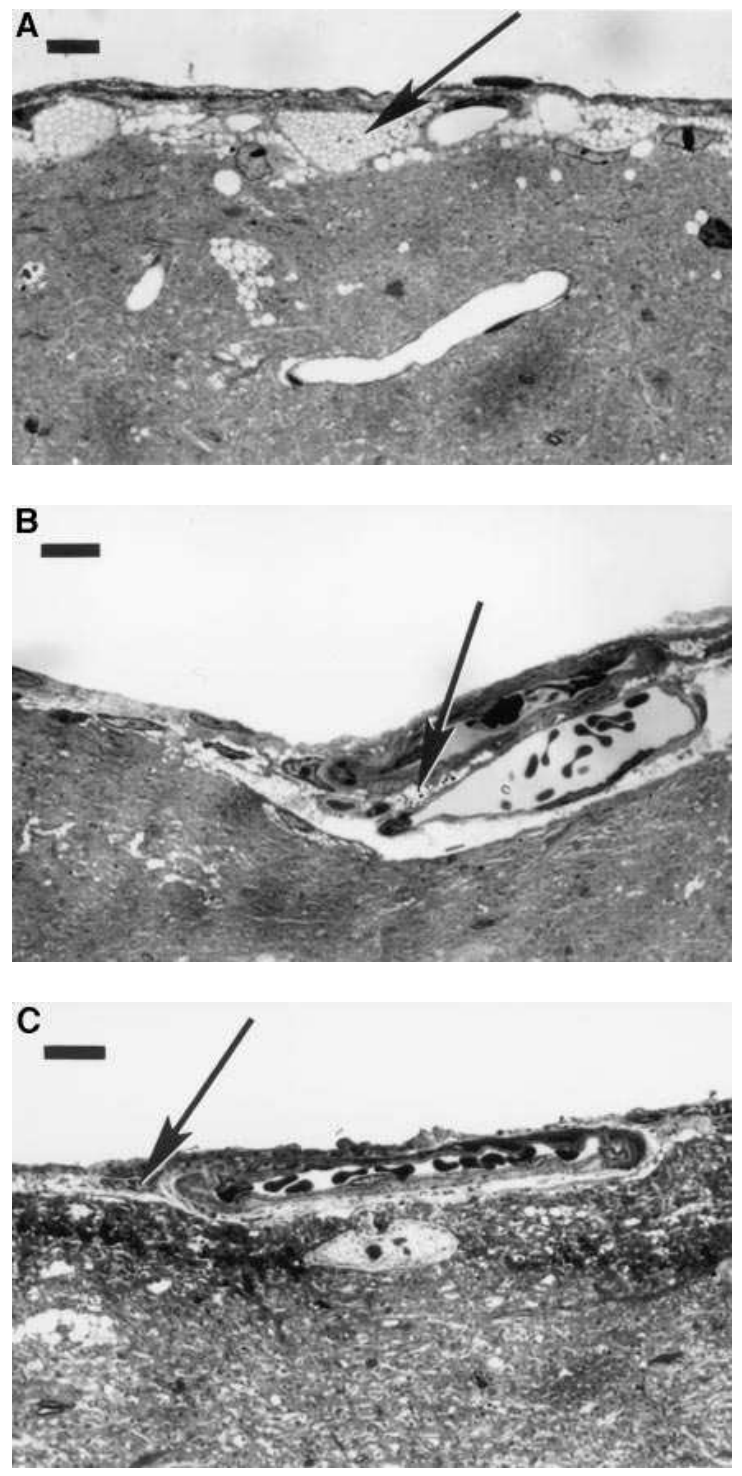

Figure 6. Abundant cytoplasmic vacuolization is seen in the meningeal fibroblasts (arrows) of an untreated MPS VII mouse $(A)$. Meningeal storage was decreased in both the Continuous ER $(B)$ and the Combined Therapy $(C)$ groups. $(A-C$ : toluidine blue, bar $=10 \mu \mathrm{m})$.

tension in the hippocampal neurons was decreased at $185 \mathrm{~d}$ of age. One possible explanation for the reduced therapeutic response in the brains of the Delayed ER group is that the $28,000-\mathrm{U}$ dose of enzyme is much smaller on a weight basis in adult mice $(\sim 0.7 \mathrm{mg} / \mathrm{kg})$ than $28,000 \mathrm{U}$ administered to newborn mice $(\sim 7 \mathrm{mg} / \mathrm{kg})$. Another possibility is that young adult mice have a more fully developed blood-brain barrier that prevents enzyme from gaining access to the brain (27). A third possible factor is that down regulation of the mannose-6-phosphate receptor in the brain during postnatal development may contribute to the poor uptake of enzyme in young adult mice (28-30).

The mechanisms of enzyme uptake and reduction of storage in the CNS by enzyme replacement and BMT are not completely understood. However, results from this and other studies suggest that early treatment for lysosomal storage diseases 

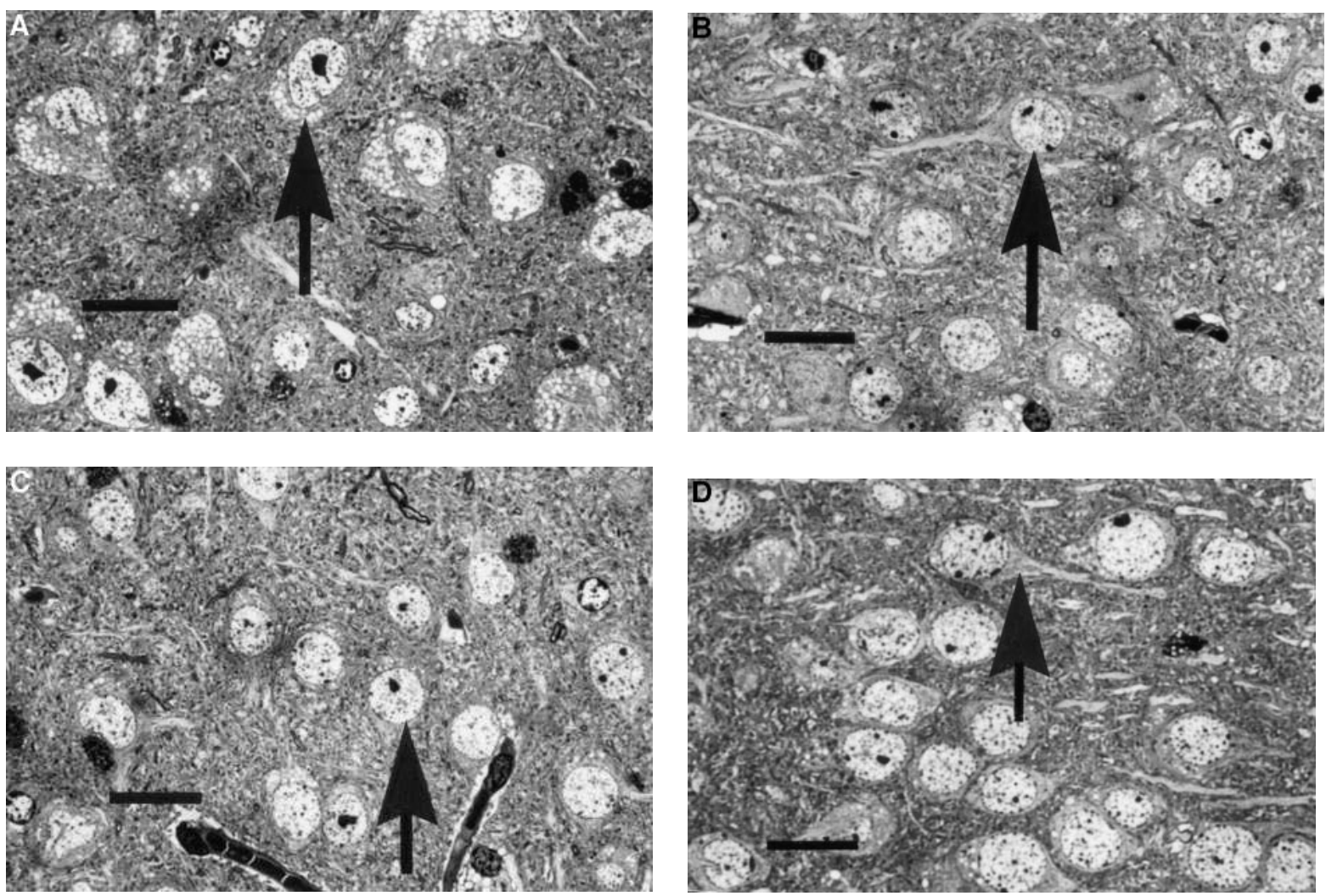

Figure 7. Cytoplasmic vacuolization was observed in neocortical neurons (arrows) of an untreated MPS VII mouse $(A)$. Neocortical neurons in the Continuous ER $(B)$, the Combined Therapy $(C)$, and the Delayed ER $(D)$ groups had less storage than untreated MPS VII mice. ( $A-D$ : toluidine blue, bar $=20 \mu \mathrm{m})$.

leads to more complete reduction of storage material in the CNS. In a canine model of fucosidosis ( $\alpha$-L-fucosidase deficiency), lysosomal storage material in the CNS is reduced to a greater extent when BMT is initiated early in life (2-4 mo of age) rather than later in life $(6-30 \mathrm{mo})(31,32)$. An increase in the life span, enzyme-containing donor cells in the CNS and remyelination of peripheral nerves was observed in a murine model of Krabbe's disease (galactosylceramidase deficiency) after BMT performed on 9-12-d-old animals (33, 34). However, no improvements in the mice were seen if the therapy was delayed until 21-28 d of age (33). Although enzyme replacement and BMT studies cannot be directly compared, it is interesting that BMT performed in 5-mo-old dogs with HurlerScheie Syndrome (MPS I) reduces lysosomal storage in the CNS (35) but enzyme replacement started at $\geq 8$ mo has no effect on the disease in the brain (36).

Combined Therapy in the MPS VII mouse produced a reduction in lysosomal storage in the same tissues that improved after enzyme replacement. In addition, lysosomal storage material was dramatically reduced in corneal fibroblasts by Combined Therapy but not by enzyme replacement alone. These results are similar to observations in MPS I dogs after BMT or $\alpha$-L-iduronidase replacement by enzyme replacement therapy $(35,36)$. The mechanisms of corneal correction by BMT is unclear. One possible mechanism might be migration of donorderived cells to the cornea that "cross correct" surrounding cells by direct cell-cell contact (37) or by receptor-mediated endocytosis of secreted enzyme (20). A recent study showed that enzyme replacement failed to reduce corneal clouding in a feline model of Maroteaux-Lamy syndrome (MPS VI) (38). Unlike MPS VII and MPS I, however, BMT did not significantly reduce corneal clouding in humans or cats with MPS VI $(39,40)$. In addition, a detailed study of reciprocal corneal transplants between cats with MPS VI and normal cats failed to demonstrate any reduction in lysosomal storage in the affected tissue (41). One study in MPS VI patients reported partial clearing of the corneal tissue adjacent to a graft from a normal donor (42), however, the methods of assessing correction were different between the human and cat studies. The variations in the extent of corneal correction after BMT highlights some of the subtle differences between individual mucopolysaccharidoses. However, the fact that there has uniformly been no reduction in corneal storage material in any lysosomal storage disease after intravenous delivery of recombinant enzyme suggests that another form of therapy is required for this tissue.

Although BMT performed in neonates was an effective means of therapy for lysosomal storage in many organs $(8,10)$, severe cerebellar dysplasia resulted from conditioning radiation in the newborn period. Cerebellar dysplasia was not seen in mice treated with the Combined Therapy in this study, demonstrating the advantage of delaying conditioning radiation until cerebellar development is more complete.

We detected antibodies directed against HSA in the $\beta$-glucuronidase preparations in MPS VII mice that received enzyme replacement therapy alone. No antibodies were detected in 
mice that received Combined Therapy. We assume the antibodies against HSA explain the adverse reactions observed in some mice after enzyme injection. We have no evidence that the anti-HSA antibodies interfered with the localization of, or therapeutic response to the injected enzyme. The distribution and levels of $\beta$-glucuronidase were comparable at $6 \mathrm{wk}$ (18), $185 \mathrm{~d}$, and $\geq 342$ days of age in mice that received enzyme injections. The reduction in lysosomal distension observed in the various tissues was also similar at the various time points with the exception of the brain in the Delayed ER group. Although antibodies to the infused enzyme itself were not seen in these studies, antibodies against infused enzyme have been reported in humans, dogs and cats that have received enzyme replacement therapy for lysosomal storage diseases. Development of antibodies does not necessarily preclude further enzyme therapy. Some humans with Gaucher disease develop antibodies to glucocerebrosidase after repeated administration of enzyme but still show a positive clinical response for at least 2-3 yr (43, 44). Dogs with Hurler-Scheie syndrome which receive enzyme injections over a 3-mo period develop antibodies to $\alpha$-L-iduronidase but still have a positive clinical response (36). In humans and dogs the severity of the immune response can be reduced effectively by pretreatment with antihistamines, by reducing the enzyme dose, or by slowing the administration rate $(36,43$, 44). Antibodies against $N$-acetylgalactosamine-4-sulfatase were detected in three cats with MPS VI after repeated enzyme injections (38). Although all three cats tolerated the injections well and had reduced lysosomal storage in visceral organs, a slightly reduced efficacy may have been observed in the cat with the highest antibody titer.

These results suggest that injection of recombinant $\beta$-glucuronidase can provide long term therapeutic benefits for MPS VII. A combination of early enzyme replacement followed by BMT appears to be as effective as enzyme replacement alone and actually leads to more complete correction in some cell types. Consistent with previous findings $(8,19)$, early initiation of therapy produces the most complete response. Given the extreme cost of life-long enzyme injections, enzyme replacement therapy may be most cost effective early in life when it has the greatest opportunity to influence development. One might rely subsequently on BMT, if a suitable donor is available, or on some form of gene therapy that allows the patients to produce their own enzyme later in life $(12,13,15)$. Should human patients with MPS VII or similar disorders benefit as dramatically from early intervention as do the animals in this study, one could argue that the current lack of newborn screening for lysosomal storage diseases may be the greatest impediment to effective therapy for this group of diseases.

\section{Acknowledgments}

We thank Dr. Jane Barker for helpful discussions throughout the study, Ann Higgins for excellent technical assistance and Dr. Tim Graubert for assistance with the statistical analysis of the survival data.

This work was supported by National Institutes of Health grants DK-41082 to E.H. Birkenmeier and C. Vogler, DK-40163 and GM34182 to W.S. Sly, and National Research Service Award grant DK08546 to M.S. Sands. The Jackson Laboratory is fully accredited by the American Association for Accreditation of Laboratory Animal Care.

\section{References}

1. Neufeld, E.F., and J. Muenzer. 1989. The mucopolysaccharidoses. In The Metabolic Basis of Inherited Disease. C.R. Scriver, A.L. Beaudet, W. Sly, and D. Valle, editors. McGraw-Hill, New York. 1565-1587.

2. Sly, W.S., B.A. Quinton, W.H. McAllister, and D.L. Rimoin. 1973. $\beta$-Glucuronidase deficiency: report of clinical, radiologic, and biochemical features of a new mucopolysaccharidosis. J. Pediatr. 82:249-257.

3. Birkenmeier, E.H., M.T. Davisson, W.G. Beamer, R.E. Ganschow, C.A. Vogler, B. Gwynn, K.A. Lyford, L.M. Maltais, and C.J. Wawrzyniak. 1989. Murine mucopolysaccharidosis VII. Characterization of a mouse with $\beta$-glucuronidase deficiency. J. Clin. Invest. 83:1258-1266.

4. Vogler, C., E.H. Birkenmeier, W.S. Sly, B. Levy, C. Pegors, J.W. Kyle, and W.G. Beamer. 1990. A murine model of mucopolysaccharidosis VII: gross and microscopic findings in $\beta$-glucuronidase-deficient mice. Am. J. Pathol. 136: 207-217.

5. Haskins, M.E., R.J. Desnick, N. Differante, P.F. Jezyk, and D.F. Patterson. 1984. $\beta$-Glucuronidase deficiency in a dog: a model of human mucopolysaccharidosis VII. Pediatr. Res. 18:980-984.

6. Sands, M.S., and E.H. Birkenmeier. 1993. A single-base-pair deletion in the $\beta$-glucuronidase gene accounts for the phenotype of murine mucopolysaccharidosis type VII. Proc. Natl. Acad. Sci. USA. 90:6567-6571.

7. Birkenmeier, E.H., J.E. Barker, C.A. Vogler, J.W. Kyle, W.S. Sly, B Gwynn, B. Levy, and C. Pegors. 1991. Increased life span and correction of the metabolic defects in murine mucopolysaccharidosis type VII after syngeneic bone marrow transplantation. Blood. 78:3081-3092.

8. Sands, M.S., J.E. Barker, C. Vogler, B. Levy, B. Gwynn, N. Galvin, W.S. Sly, and E.H. Birkenmeier. 1993. Treatment of murine mucopolysaccharidosis type VII by syngeneic bone marrow transplantation in neonates. Lab. Invest. 68:676-686.

9. Berry, C.L., C. Vogler, N.J. Galvin, E.H. Birkenmeier, and W.S. Sly. 1994. Pathology of the ear in murine mucopolysaccharidosis type VII: morphological correlates of hearing loss. Lab. Invest. 71:438-445.

10. Sands, M.S., L.C. Erway, C. Vogler, W.S. Sly, and E.H. Birkenmeier. 1995. Syngeneic bone marrow transplantation reduces the hearing loss associated with murine mucopolysaccharidosis type VII. Blood. 86:2033-2040.

11. Bastedo, L., M.S. Sands, D.T. Lambert, M.A. Pisa, E.H. Birkenmeier, and P.L. Chang. 1994. Behavioral consequences of bone marrow transplantation in the treatment of murine mucopolysaccharidosis type VII. J. Clin. Invest. 94:1180-1186

12. Wolfe, J.H., M.S. Sands, J.E. Barker, B. Gwynn, L. Rowe, C.A. Vogler, and E.H. Birkenmeier. 1992. Reversal of pathology in murine mucopolysaccharidosis type VII by somatic cell gene transfer. Nature (Lond.). 360:749-753.

13. Marechal, V., N. Naffakh, O. Danos, and J.M. Heard. 1993. Disappearance of lysosomal storage in spleen and liver of mucopolysaccharidosis VII mice after transplantation of genetically modified bone marrow stem cells. Blood. 82:1358-1365.

14. Moullier, P., V. Marechal, O. Danos, and J.M. Heard. 1993. Continuous systemic secretion of a lysosomal enzyme by genetically modified mouse skin fibroblasts. Transplantation (Baltimore). 56:427-432.

15. Moullier, P., D. Bohl, J.M. Heard, and O. Danos. 1993. Correction of lysosomal storage in the liver and spleen of MPS VII mice by implantation of genetically modified bone marrow stem cells. Nat. Genet. 4:154-159.

16. Grubb, J.H., J.W. Kyle, L.B. Cody, and W.S. Sly. 1993. Large scale purification of phosphorylated recombinant human $\beta$-glucuronidase from overexpressing mouse L cells. FASEB J. 7:1255a. (Abstr.).

17. Vogler, C., M.S. Sands, A. Higgins, B. Levy, J. Grubb, E.H. Birkenmeier, and W.S. Sly. 1993. Enzyme replacement with recombinant $\beta$-glucuronidase in the newborn mucopolysaccharidosis type VII mouse. Pediatr. Res. 34:837-840.

18. Sands, M.S., C. Vogler, J.W. Kyle, J.H. Grubb, B. Levy, N. Galvin, W.S. Sly, and E.H. Birkenmeier. 1994. Enzyme replacement therapy for murine mucopolysaccharidosis type VII. J. Clin. Invest. 93:2324-2331.

19. Vogler, C., M.S. Sands, B. Levy, N. Galvin, E.H. Birkenmeier, and W.S. Sly. 1996. Enzyme replacement with recombinant $\beta$-glucuronidase in murine mucopolysaccharidosis type VII: impact of therapy during the first six weeks of life on subsequent lysosomal storage, growth, and survival. Pediatr. Res. 39: $1050-1054$.

20. Fischer, H.D., A. Gonzalez-Noriega, and W.S. Sly. 1980. $\beta-G l u c-$ uronidase binding to human fibroblast membrane receptors. J. Biol. Chem. 255: 5069-5074.

21. Glaser, J.H., and W.S. Sly. 1973. $\beta$-Glucuronidase deficiency mucopolysaccharidosis: methods for enzymatic diagnosis. J. Lab. Clin. Med. 82:969977

22. Gabel C.A., D.E. Goldberg, and S. Kornfeld. 1983. Identification and characterization of cells deficient in the mannose 6-phosphate receptor: evidence for an alternate pathway for lysosomal enzyme targeting. Proc. Natl. Acad. Sci. USA. 80:775-779.

23. Watson, G., M. Felder, L. Rabinow, K. Moore, C. Labarca, C. Tietze, G. Vander Molen, L. Bracey, M. Brabant, J. Cai, and K. Paigen. 1985. Properties of rat and mouse $\beta$-glucuronidase mRNA and cDNA, including evidence for sequence polymorphism and genetic regulation of mRNA levels. Gene (Amst.). 
$36: 15-25$.

24. Bradford, M.M. 1976. A rapid and sensitive method for the quantitation of microgram quantities of protein utilizing the principle of protein dye binding. Anal. Biochem. 72:248-254.

25. Wolfe, J.H., and M.S. Sands. 1996. Murine mucopolysaccharidosis type VII: a model system for somatic gene therapy of the central nervous system. In Gene Transfer into Neurones, Towards Gene Therapy of Neurological Disorders. P. Lowenstein and L. Enquist, editors. J. Wiley and Sons, Essex, United Kingdom. 263-274.

26. Kaplan, E.L., and P. Meier. 1958. Nonparametric estimation from incomplete observations. J. Am. Stat. Assoc. 53:457-463.

27. Laterra, J.J., P.A. Stewart, and G.W. Goldstein. 1992. Development of the blood brain barrier. In Fetal and Neonatal Physiology. A. Polin and W.W. Fox, editors. W.B. Saunders Co., Philadelphia, PA. 1525-1531.

28. Sklar, M.M., W. Kiess, C.L. Thomas, and S.P. Nissley. 1989. Developmental expression of the tissue insulin-like growth factor II/mannose 6-phosphate receptor in the rat. J. Biol. Chem. 264:16733-16738.

29. Senior, P.V., S. Byrne, W.J. Brammar, and F. Beck. 1990. Expression of the IGF II/mannose 6-phosphate receptor mRNA and protein in the developing rat. Development (Camb.). 109:67-73.

30. Matzner, U., K. Von Figura, and R. Pohlmann. 1992. Expression of the two mannose 6-phosphate receptors is spatially and temporally different during mouse embryogenesis. Development (Camb.). 114:965-972.

31. Taylor, R.M., G.J. Stewart, B.R.H. Farrow, and P.J. Healy. 1986. Enzyme replacement in nervous tissue after allogeneic bone marrow transplantation for fucosidosis in dogs. Lancet. ii:772-774.

32. Taylor, R.M., B.R.H. Farrow, and G.J. Stewart. 1992. Amelioration of clinical disease following bone marrow transplantation in fucosidase-deficient dogs. Am. J. Med. Genet. 42:628-632.

33. Yaeger, A.M., S. Brennan, C. Tiffany, H.W. Moser, and G.W. Santos. 1984. Prolonged survival and remyelination after hematopoietic cell transplantation in the twitcher mouse. Science (Wash. DC). 225:1052-1054.

34. Hoogerbrugge, P.M., K. Suzuki, K. Suzuki, B.J.H.M. Poorthuis, T. Kobayashi, G. Wagemaker, and D.W. van Bekkum. 1988. Donor-derived cells in the central nervous system of twitcher mice after bone marrow transplanta- tion. Science (Wash. DC). 239:1035-1038.

35. Shull, R.M., N.E. Hastings, R.R. Selcer, J.B. Jones, J.R. Smith, W.C. Cullen, and G. Constantopoulos. 1987. Bone marrow transplantation in canine mucopolysaccharidosis I: effects within the central nervous system. J. Clin. Invest. 79:435-443.

36. Shull, R.M., E.D. Kakkis, M.F. McEntee, S.A. Kania, A.J. Jonas, E.F. Neufeld. 1994. Enzyme replacement in a canine model of Hurler syndrome. Proc. Natl. Acad. Sci. USA. 91:12937-12941.

37. Olsen, I., H. Muir, R. Smith, A. Fensom, D.J. Watt. 1983. Direct enzyme transfer from lymphocytes is specific. Nature (Lond.). 306:75-77.

38. Crawley, A.C., D.A. Brooks, V.J. Muller, B.A. Petersen, E.L. Isaac, J. Bielicki, B.M. King, C.D. Boulter, A.J. Moore, N.L. Fazzalari, et al. 1996. Enzyme replacement therapy in a feline model of Maroteaus-Lamy Syndrome. $J$. Clin. Invest. 97:1864-1873.

39. Krivit W., M.E. Pierpont, K. Ayaz, M. Tsai, N.K.C. Ramsay, J.H. Kersey, S. Weisdorf, R. Sibley, D. Snover, M.M. McGovern, et al. 1984. Bone-marrow transplantation in the Maroteaux-Lamy Syndrome (mucopolysaccharidosis type VI). N. Engl. J. Med. 311:1606-1611.

40. Haskins, M., H. Baker, E. Birkenmeier, P. Hoogerbrugge, B. Poorthuis, T. Sakiyama, R. Shull, R. Taylor, M. Thrall, and S. Walkley. 1991. Transplantation in animal model systems. In Therapy of Genetic Diseases. R. Desnick, editor. Churchill Livingston Inc., New York. 183-201.

41. Aguirre, G., I. Raber, M. Yanoff, and M. Haskins. 1992. Reciprocal corneal transplantation fails to correct mucopolysaccharidosis VI corneal storage. Invest. Opthal. Vis. Sci. 33:2702-2713.

42. Naumann, G. 1985. Clearing of cornea after perforating keratoplasty in mucopolysaccharidosis type VI (Maroteaux-Lamy Syndrome). N. Engl. J. Med. 312:995.

43. Pastores, G.M., A.R. Sibille, and G.A. Grabowski. 1993. Enzyme therapy in Gaucher disease type I: dosage efficacy and adverse effects in 33 patients treated for 6 to 24 months. Blood. 82:408-416.

44. Richards, S.M., T.A. Olson, and J.M. McPherson. 1993. Antibody response in patients with Gaucher disease after repeated infusion with macrophage-targeted glucocerebrosidase. Blood. 82:1402-1409. 